\title{
De sirenis: imagem e mito na literatura moderna
}

\author{
De sirenis: image and myth in modern literature
}

\author{
Maria Alice Ribeiro Gabriel ${ }^{1}$
}

\begin{abstract}
Resumo: Este artigo tenciona apresentar uma análise crítica da imagem da sereia em suas fontes e por meio de sua evolução, do episódio épico descrito por Homero à narrativa moderna. Os discursos da historiografia, literatura e religião contam o mito assumindo características distintas, mesclando-as a contextos literários, filosóficos e sociais. As implicações desses contextos afetaram a representação do mito em sua forma literária. Uma revisão historiográfica e literária dos textos de Manuel Bernardes, Gilberto Freyre, Joaquim Ruyra e José Cândido de Carvalho mostram que as diferenças entre essas versões são menores após o século XVII. As variantes do mito são examinadas de acordo com os estudos de Dana Oswald, Lisa Verner, e Luís da Câmara Cascudo.
\end{abstract}

Palavras-chave: História. Literatura. Híbrido. Sereia.

Abstract: This paper intends to present a critical examination of the siren's image in its sources and evolution, from the epic episode described by Homer to the modern narrative. The discourses of historiography, literature, and religion tell the myth assuming some distinct features, blending them with literary, philosophical, and social contexts. Implications of these contexts have affected the aesthetic representation of the myth in its literary form. A historiographic and literary review of Manuel Bernardes's, Gilberto Freyre's, Joaquim Ruyra's, and José Cândido de Carvalho's texts shows that differences between these versions are minor after the seventeenth century. The variants of the myth are examined based on studies undertaken by Dana Oswald, Lisa Verner, and Luís da Câmara Cascudo. Keywords: History. Literature. Hybrid. Siren.

\section{Introdução}

When I reached the seashore I saw three sirens, at the wave's edge, combining their green hair with a golden comb. (André Gide, in memorian)

Em seu árduo retorno de Tróia, Ulisses enfrentou muitas provas e tentações. Uma delas - a primeira ele venceu ao escapar das garras da bela feiticeira Circe - é o seu encontro com as sereias. Homero não as descreveu. As artes visuais representaram-nas como criaturas tendo cabeça de mulher e corpo de pássaro. A imagem da "Siren" figurada na Grécia antiga não é precisamente clara, o que é "certo", conforme Alfred Heubeck e Arie Hoekstra (1988-92, p. 119 apud SHANKMAN; DURRANT, 2000, p. 12), é a concepção e os retratos dos híbridos humanos terem sido influenciados por modelos orientais, provavelmente do Oriente Médio. A aparência híbrida da sereia atesta não só a ambivalente combinação das naturezas de Eros e Thanatos, a antítese prazer e destruição, mas a assimilação de modelos culturais.

Paralelos e assincronias podem ser traçados na representação da imagem da sereia, na literatura e na crônica ou relato histórico. Ambas as modalidades textuais registram descrições do mito com agudos contrastes. Mesmo as narrativas que não representam a sereia como um monstro sedutor não necessariamente excluem o belo e o sublime de sua caracterização. O corpo, associado a outros encantos aos quais se rendem os que da sereia se aproximam - a juventude, a voz, as promessas - sugere um 
exercício de autocontrole para o herói mítico, mas há variações do mito, a exemplo da narrativa "Las damiselas del mar” (1909), do escritor Joaquim Ruyra.

Analisando a participação dos modelos de colonização, circunstâncias históricas, fatores ambientais e laborais na composição de narrativas folclóricas, John Alan Cicala (2007) lembrou a pesquisa empreendida na Hungria pela folclorista Linda Dégh, no início dos anos sessenta, junto a operários protestantes das indústrias de aço e petróleo, coletando histórias tradicionais, crenças, canções e costumes quase extintos do "antigo país”. Segundo Dégh (1966 apud CICALA , 2007, p. 397), tradições folclóricas rurais constituídas de formas arcaicas e novos elementos perduraram devido à flexibilidade permitida pela assimilação e adaptação das tradições de grupos étnicos à cultura nativa. Interrogado sobre a existência de sereias na área, um trabalhador aposentado explicou à folclorista que tais criaturas jamais sobreviveriam às águas geladas do lago Michigan, mas infestariam - "flourished" - as águas quentes do Golfo da Flórida.

$\mathrm{O}$ relato de alguém descrevendo a experiência imediata com o desconhecido pode tornar-se fonte para versões de "segunda mão", orais e impressas, regionais e nacionais, divorciadas da versão original, recontadas em memorates e fabulates. Pelo acréscimo de variantes, transmitidas por canais de comunicação diversificados, uma história seria reformulada. Assim, ramificações posteriores da percepção de "primeira mão" poderiam moldar uma legenda, esclareceu Dégh (2001, p. 68-69).

No ensaio "Revolution in Popular Culture" (2006), Peter Burke recordou o termo bricolage, cunhado por Lévi-Strauss (1966), ao explicar a reconstrução de elementos tradicionais ou de "segunda mão" na formação de um sistema cultural, bem como a incorporação de novos elementos por um antigo sistema. A ideia permitiria ao historiador discutir a continuidade $\mathrm{e}$ a mudança cultural sem exagerar a importância da tradição, sendo particularmente útil no estudo da cultura popular para se observar a reinterpretação de elementos "externos" em um processo de incorporação. Logo, diferentes linhas de pesquisa convergiriam para a mesma meta por variadas rotas.
Lévi-Strauss propôs um caminho inovador para leitura dos mitos. Mais tarde, Jacques Le Goff e Emmanuel Le Roy Ladurie ofereceram interpretações da legenda medieval - da sereia melusina, por exemplo - nos termos de Lévi-Strauss, porém utilizando os resultados em quadro mais tradicional (BURKE, 2006, p. 43).

Do ponto de vista sociológico, em complementação ao debate historiográfico, outra posição é conferida à legenda e ao mito na introdução de Assombrações do Recife Velho (1955), de Gilberto Freyre (2000, p. 35): "Os mistérios que se prendem à história do Recife são muitos: sem eles o passado recifense tomaria o frio aspecto de uma história natural. E pobre da cidade ou do homem seja só história natural".

Ao fundamentar o discurso literário, o passado é usado como um arquivo empírico da experiência abstrata cristalizada em um repertório de narrativas acessíveis ao escritor e passível de modificação conforme sua percepção estética. A visão do mito, segundo descrição do mundo natural, é ampliada pela interpretação e atributos da imaginação do autor. Considerando essa premissa, as reflexões deste artigo centram-se nas representações da imagem da sereia na literatura, inicialmente, a partir de suas antigas fontes, incluindo a crônica histórica, apoiando-se nos estudos de Câmara Cascudo, Dana Oswald e Roberta Milliken. Em seguida, discute-se a interpretação e a forma emprestada ao mito nos textos de Manuel Bernardes, Joaquim Ruyra, Gilberto Freyre e José Cândido de Carvalho.

\section{Crônica, mito e história natural}

Roberta Milliken (2012, p. 123) associou a evolução da figura da sereia à tendência de enfatizar o aspecto ameaçador da feminilidade. A poderosa imagem da antiga sereia, mulher pássaro, foi lentamente eclipsada pela da sereia mulher peixe. No processo, a espiritual e talentosa sereia reduziu-se a um simples emblema da sensualidade dissimulada. Esssa alteração cumpriu-se gradualmente na Idade Média.

No ensaio "Monstrous Gender: Geographies of Ambiguity" (2012), Dana Oswald ilustrou tal modificação com descrições clássicas de sereias 
retratadas na forma híbrida de mulher pássaro nas pinturas de vasos gregos e afrescos romanos. Na Idade Média, o Liber Monstrorum apresentaria outra definição em "De Sirenis”:

As sereias são donzelas marinhas, cuja esplêndida presença e doçura do canto seduzem os navegantes, e da cabeça ao umbigo seus corpos virginais assemelham-se ao gênero humano, mas possuem caudas escamosas de peixe, sempre ocultas entre as águas ${ }^{2}$ (ORCHARD, 1995, p. 262-263 apud OSWALD, 2012, p. 352, tradução nossa).

A contextualização do mito, reinterpretado pela visão do explorador europeu mostra uma radical transformação. Durante o domínio holandês no Brasil, Gaspar Barleu, "[...] fiel às tradições europeias dos homens-marinhos e toda uma fauna assombrosa, não discutiu a crença e registrou o Ipupiara" (CASCUDO, 1993, p. 460): "Os tritões, chamados ipupiaras pelos índios, são peixes maravilhosos de ver, pois lembram de alguma forma o rosto humano, com aspectos elegante e o cabelo comprido de uma mulher" (BARLÉU, 2018, p. 67, grifo do autor).

Se as descrições do Liber Monstrorum e de Barleu aproximam-se, talvez a última concilie poeticamente culturas distintas, ressaltando o aspecto humano, os fluidos cabelos e faces elegantes das fêmeas do Ipupiara, o tritão indígena.

Sereias, em ambas as tradições, são sempre fêmeas, sedutoras e perigosas, filiadas às águas e effluvia, mas estranhamente isentas da capacidade sexual, devido à sua metade pássaro ou peixe. Desse modo, simultaneamente provoca desejo e adverte sobre a natureza destrutiva do apetite sexual; em contraste, o corpo híbrido sugere monstruoso gênero hipersexualizado. Poucos monstros na iconografia medieval sugeririam categoria ou gênero alternativo firmado não em sua natureza bestial, mas na capacidade de sedução (OSWALD, 2012, p. 352).

"No Brasil dos séculos XVI e XVII não havia a mãe-d'água atual. $O$ indígena, pela sua concepção teogônica, não podia admitir a sedução sexual nas cis, as mães, origem de tudo." (CASCUDO, 1993, p. 532, grifos do autor). No mito indígena original, a mãe-d'água possuía forma ofídica, ligada às serpentes boiúna e mboiaçu.

\begin{abstract}
Nem o mito ameríndio das ci (mães) podia, psico e morfologicamente, compreender as sereias e nixes brancas da Europa, brancas, louras, cantoras, tendo a monomania da excitação sexual exclusiva. O que havia no Brasil indígena de quinhentos e seiscentos era o Ipupiara (CASCUDO, 1993, p. 460-461).
\end{abstract}

A influência do modelo extraído da mitologia greco-latina é revista através dos escritos de cronistas e expedicionários, como uma alternativa que se insere no contexto das novas descobertas territoriais e no registro de uma fauna maravilhosa.

Câmara Cascudo (1993, p. 460) nota que a documentação dos seiscentos e setecentos não registrou no Brasil ente marinho com forma humana, exceto o "bestial" Ipupiara: "Nada existe, em quase duzentos anos coloniais, lembrando a convencional Iara, nem o mito da mãe-d'água com as cores e atributos sedutores dos ciclos mediterrâneos, as sereias irresistíveis". O autor distinguiu os termos mãe-d'água e sereia, ressalvando: "Nenhum cronista do Brasil colonial registra a mãe-d'água como sereia, atraindo pelo canto ou simplesmente transformada em mulher. É sempre o Ipupiara, feroz, faminto e bruto" (CASCUDO, 1993, p. 533).

O ipú-piara, habitante das fontes e profundezas das águas, consta entre os "[...] mais antigos mitos brasileiros registrados pelos cronistas coloniais" (CASCUDO, 1993, p. 459). O padre José de Anchieta descreveu-o em 1560; o jesuíta Fernão Cardim "fixou-os" nos escritos redigidos no final do século XVI; no início do século XVII, Frei Vicente de Salvador mencionou os "homens-marinhos", mas não os descreveu; o padre Simão de Vasconcelos declarou ter visto lapas repletas de ossadas de homens-peixes

2 Do original: Sirenae sunt marinae puellae, quae nauigantes pulcherrima forma et cantu dulcedinis decipieunti, et a capite usque ad umbilicum sunt corpora uirginali et humano generi simillimae, squamosas tamen piscium caudas habent, quibus simper in gurgite latente. 
e peixes-mulheres: "[...] vi suas caveiras, que não tinham mais diferença de homem e mulher, que um buraco no toutiço, por onde dizem que respiravam" (CASCUDO, 1993, p. 560). Pero de Magalhães Gândavo assim relatou "Do monstro marinho que se matou na capitania de São Vicente no ano de 1564":

Na Capitania de São Vicente, sendo já alta noite, a horas em que todos começavam se entregar ao sono, acertou de sair fora de casa uma índia escrava do capitão, a qual, lançando os olhos a uma várzea que está pegada ao mar, e com a povoação da capitania, viu andar nela este monstro, movendo-se de uma parte para outra, com passos e maneios desusados, e dando alguns urros de quando em quando, tão feios, que como pasmada e quase fora de si, a índia se veio ao filho do capitão, cujo nome era Baltazar Ferreira, e lhe deu conta do que vira, parecendo-lhe que era alguma visão diabólica. Mas como ele fosse homem não menos sisudo que esforçado, e esta gente da terra seja digna de pouco crédito, não lho deu logo muito a suas palavras, e deixando-se estar na cama, a tornou outra vez a mandar fora, dizendo-lhe que se afirmasse bem no que era (GÂNDAVO, 2004, p. 137-138).

Segundo Mary Del Priore (2000, p. 91), a imagem que Gândavo apresentou do monstro Ipupiara destoaria das encantadoras sereias que seduziram o herói grego: "[...] cabeça e focinho de cão, seios femininos, mãos e braços humanos e patas de ave de rapina. No meio do corpo, uma cloaca. A Ipupiara estaria longe de sugerir a beleza das sereias capazes de seduzir incautos marinheiros". O animal parece ser visto pelo indígena e pelo europeu como um elemento de dimensão sobrenatural:

O retrato desse monstro é este que no fim do presente capítulo se mostra, tirado pelo natural. Tinha quinze palmos de comprido e semeado de cabelos pelo corpo, e no focinho tinha umas sedas mui grandes como bigodes. Os índios da terra lhe chamam em sua língua ipupiara, que quer dizer demônio d’água (GÂNDAVO, 2004, p. 130).

Homem de seu tempo, apesar de reconhecer "os segredos da natureza”, Gândavo reconhece também o seu aspecto admirável. Historicamente, mais de uma vez o desconhecido foi consignando ao âmbito do inexplicável e do maravilhoso:

E assim também deve de haver outros muitos monstros de diversos pareceres que no abismo desse largo e espantoso mar se escondem, de não menos estranheza e admiração; e tudo se pode crer, por difícil que pareça: porque os segredos da natureza não foram revelados todos ao homem para que com razão possa negar e ter por impossíveis as coisas que não viu, nem de que nunca teve notícia (GÂNDAVO, 2004, p. 131).

O informe de Gabriel Soares de Sousa, apresentado no capítulo CXXVII do Tratado descriptivo do Brazil em 1587, "Que trata dos homens marinhos", não os descreve, mas registra testemunhos que descrevem os danos causados por eles:

Não ha duvida senão que se encontram na Bahia e nos reconcavos d'ella, muitos homens marinhos, a que os índios chamam pela sua língua upupiara, os quaes andam pelo rio d'agua doce pelo tempo do verão, onde fazem muito damno aos índios pescadores e mariscadores [...] a uns e outros apanham, e mettem-nos debaixo d'agua onde os afogam [...] e dizem outros índios pescadores que viram tomar a estes mortos que viram sobre água uma cabeça de homem lançar um braço fora d'ella e levar o morto; e os que isso viram fugindo á terra assombrados [...] os quaes fantasmas e homens marinhos mataram por vezes cinco índios meus (SOUSA, 1851, p. 280).

"Gabriel Soares de Sousa apresenta-se como alguém dotado de grande intimidade com o assunto e como testemunha 'quase' direta da existência do monstro" (PRIORE, 1993, p. 91, ênfase da autora). Observe-se, no trecho anterior e no seguinte, a transformação do fabulate - a legenda do "homem marinho" - personalizado em memorate pelo cronista:

E um mestre de assucar do meu engenho afirmou que olhando da janella do engenho que está sobre o rio, e que gritavam umas negras, uma noite, que estavam lavando umas fòrmas de assucar, viu um vulto maior que um homem á borda d'agua, mas que se lançou logo n'ella; ao qual mestre de 
assucar as negras disseram que aquella fantasma vinha para pegar n'ellas, e que aquelle era o homem marinho [...] (SOUSA, 1851, p. 280).

Nota-se o aumento do número dos transmissores que ouviram a história, os quais, em certa medida, conferem-lhe crédito no momento de recontá-la a outros. Dégh (2001, p. 69) questionou o valor da evidência de testemunhas oculares presumivelmente desconhecidas, verificando a importância do testemunho na constituição do memorate: é necessário que alguém tenha avistado o "fantasma", o ser fabuloso ou aparição sobrenatural e relatado a sua experiência pessoal a outrem.

“Os Tratados de Fernão Cardim permitem-nos ter um conhecimento aproximado da terra brasileira do Quinhentos, já que são descrições em primeira mão", comentou Ana Maria de Azevedo (2009, p. 31), em prefácio à obra do jesuíta. A presença do conhecimento indígena é visível na obra de Cardim, pela utilização do vocabulário tupi referente à fauna e à flora nativa. A descrição do Ipupiara integra a "antropologia fantasista" de raízes ibéricas, comum aos cronistas portugueses (AZEVEDO, 2009, p. 33). Os "Homens marinhos, e monstros do mar" ou Igpupiara:

[...] parecem-se com homens propriamente de boa estatura, mas têm os olhos muito encovados. As fêmeas parecem mulheres; têm os cabelos compridos e são formosas; acham-se estes monstros nas barras dos rios doces (CARDIM, 2009, p. 151).

Apesar de admitir a natureza ficcional, imaginária, de alguns monstros, Santo Isidoro de Sevilha dedicou-lhes espaço significativo nas Etimologias, descrevendo-os com o propósito de melhor apreender a "causa das coisas". O arcebispo pretendia, notou Lisa Verner (2005, p. 33), registrar e validar noções espirituais, ainda que materialmente infundadas. $\mathrm{O}$ sentido em que monstros ficcionais são atinentes à verdade é literário. Nesta acepção, ele interpretou a existência das sereias, aplicando a força da imagem à ilustração do discurso de cunho moralizante:

As três sereias eram figuradas metade donzela, metade pássaro, dotadas de garras e asas; a primeira cantava com a voz, a segunda com a flauta, a terceira com a lira. Através do canto, levavam os navegantes encantados ao naufrágio. Na verdade, eram meretrizes, destruidoras dos passantes, que naufragavam sob seus artifícios. Por isso, afirma-se que têm asas e unhas, pois a luxúria voa e fere, e que permanecem entre as ondas, porque Vênus surgiu das águas ${ }^{3}$ (SEVILHA, apud VERNER, 2005, p. 34, tradução nossa).

Antônio Vieira empregou o termo sereia, em 1654, no "Sermão de Santo Antônio aos Peixes", pregado em São Luís do Maranhão. O procedimento retórico utilizado na exegese é semelhante ao de Isidoro de Sevilha, advertindo sobre o mal:

Quantos, na nau Sensualidade, que sempre navega com cerração, sem sol de dia, nem estrelas de noite, enganados do canto das sereias e deixando-se levar da corrente, se iriam perder cegamente, ou em Sila, ou em Caribdes, onde não aparecesse navio nem navegante, se a rémora da língua de António os não contivesse, até que esclarecesse a luz e se pusessem em vista (VIEIRA, 2010, p. 432).

O relato fantasioso de Francisco Corrêa, escrito entre 1693 e 1699, em Relação do Sucesso que teve o Patacho chamado Nossa Senhora da Candelária, da Ilha da Madeira, o qual vindo da Costa da Guiné, no ano de 1693, uma rigorosa tempestade o fez varar na Ilha incógnita (s. d.), descreve a mulher marinha "com todas as perfeições até a cinta”, um amálgama de melusina e dama pé de cabra:

Trabalhou-se todo o dia e deixando vigias, descansámos e na manhã seguinte, que se contavam sete de Agosto, ainda mal se divisava a luz quando

3 Do original: Sirenas tres figurunt fuisse ex parte virgines, ex parte volucres, habentes alas et úngulas: quarum una voce, altera tibiis, tertia lira canebant. Quae inlectos navigantes sub cantu in naufragium traebant. Secundum veritatem autem meretrices fuerunt, quae trauseuntes quoniam deducebant ad egestatem, his fictae sunt inferre naufragia. Alas autem habuisse et úngulas, quia amor et volat et vulnerat. Quae inde in fluctibus conmorasse dicuntur, quia fluctus Venerem creaverunt. 
vimos sair das águas uma mulher marinha e com tanta ligeireza entrou na terra e subiu ao monte que não tiveram todos os companheiros o gosto de a verem. Tinha todas as perfeições até à cinta que se discorrem na mais formosa e somente a desfeavam as grandes orelhas que tinha, pois lhe subiam à distância de mais de meio palmo por cima da cabeça. Da cinta para baixo toda estava coberta de escamas e os pés eram do feitio de cabra, com barbatanas pelas pernas. Tanto que se viu no monte, pressentindo ser vista, deu tais berros que estremecia a Ilha pelo retombo dos ecos e saíram tantos animais e de tão diversas castas que nos causou muito medo. Arrojou-se finalmente ao mar pela outra parte com tal ímpeto que sentimos nas águas a sua veemência. [...] Todos se assustaram, menos eu, pois já tinha visto outra no Cabo de Gué, e tinha perdido o medo com outras semelhantes aparições, e me lembra que, junto a Tenerife, vi um homem marinho de tão horrendo feitio, que parecia o mesmo Demónio (LANCIANI, 1979, p. 56).

O explorador e naturalista Henry Walter Bates, por volta de 1850, no Amazonas, descreveu o boto capaz de transformar-se em mulher, "de cabeleira solta”, atraindo os rapazes com intenção de afogá-los. Entretanto, Câmara Cascudo adverte que o boto não é a mãe-d’água. Esta, conhecida em todo o Brasil, evoca a:

[...] sereia europeia, alva, loura, meia peixe, cantando para atrair o enamorado que morre afogado querendo acompanhá-la para bodas no fundo das águas. O mito é morfologicamente europeu, do ciclo atlântico, posterior à poesia de Homero, para quem as sereias eram aves e não peixes cantando. [...] Há, espalhadamente, a sereia, meia mulher e tendo o apêndice caudal dos peixes, por todos os mares e rios da Europa, desde as russalcas eslavas às nixes fluviais do Reno (CASCUDO, 1993, p. 532).

A Loreley do Reno, cuja música leva o barco do enamorado em direção às pedras, "na fórmula clássica das sereias homéricas"; as mães-d'água; as nereidas; as "ninfas que mataram Hilas, companheiro de Hércules"; as nixes; as russalcas que levam o namorado “[...] para o fundo das águas, onde têm palácios, e aí o matam a cócegas" (CASCUDO, 1993, p. 532); todas, cantando ou não, compelem à destruição.

A partir da Idade Média, conforme observou Verner (2005, p. 42), cristianizados, os monstros, incluindo as sereias, tornaram-se menos efetivos e interessantes, precisamente, devido ao imperativo cristão para catalogar, organizar e interpretar suas estranhas manifestações. Apesar do esforço de exegetas, teólogos e viajantes para conciliar os domínios do conhecimento e do maravilhoso, os monstros resistiam à categorização, pois não podiam ser examinados e explicados por completo.

\section{História, literatura e sobrenatural}

Na época clássica, da qual é herdeiro o texto de Bernardes, as letras formavam um dispositivo em que três polos - criação, crítica e educação - coincidiam perfeitamente, de acordo com JeanLouis Jeannelle e Gilles Philippe (2006, p. 40). Um classicismo, para Judith Schlanger (1992, p. 52), é um círculo onde se encontram em jogo os mesmos valores e prédicas que ele se encarrega de produzir, apreciar e ensinar. À literatura caberia dar-lhe forma e movimento pela transmissão.

A "Lenda da mulher marinha", de Bernardes, apenas destitui a sereia da metade peixe: "era mulher, e por extremo formosa”, contudo, "perseverava muda”. A bela é encontrada durante uma noite em que, na "Sicília, certo mancebo robusto e animoso, e grande nadador" foi banhar-se no mar. O enamorado levou-a para casa:

Lançando-lhe pois a mão aos cabellos, a foi levando à toa para a terra; onde saindo reconheceu que era mulher, e por extremo formosa [...] e não se contentando com menos que com recebe-la por sua mulher; achando que sobre sua rara formosura, bem raro era também o dote de saber calar, e não lhe conhecerem parentes. E a seu tempo teve d'ella um filho mui lindo, com que vivia contente da eleição que fizera, e já não reparava no perpétuo silêncio de sua consorte, attribuindo a defeito natural com que havia nascido (BERNARDES, 1865, p. 95). 
A versão de Bernardes recorda a lenda compilada por Alexandre Herculano, "A Dama do Pé de Cabra", tendo a sua forma, remanescente da literatura medieval, adaptada ao tópico moralizante, em continuidade ao gênero do exemplum. Embora a mulher marinha não tenha corpo de híbrido, Bernardes (1865, p. 96) define-a como ente maligno: "Pelo que eu vejo, essa não é mulher, mas demônio em figura d'ella" e sereia: "E foi que, crescendo em annos, e seguindo os costumes do pai, quando um dia andava nadando com outros, veio de repente aquella mesma Sêrea, e à vista de todos o levou consigo, onde nunca mais foi visto" (BERNARDES, 1865, p. 97). Nesse contexto, segundo arguiu Tara E. Pedersen (2015, p. 27), a sereia expressaria, como figura perpetuamente desconhecida, a tentativa de apreender o inexplicável, representado em sua natureza sedutora e no perigo do desejo pelo corpo "exótico".

No conto de Joaquim Ruyra, as donzelas marinhas evocam duas imagens de William Shakespeare: a Rainha Mabe, diminuta fada dos sonhos, citada em Romeu e Julieta por Mercúcio e o séquito de Titânia, em Sonho de uma Noite de Verão:

São brancas como a carne pálida do peixe. Em seus cabelos finíssimos brincam tonalidades irisadas; brilham em suas cabeças pentes de escama; seus mantos são verdes, são longos, longos, arrastadiços; por olhos, têm gotinhas de luz como as que às vezes produzem na água o roçar dos remos. À sua passagem desprendem agradavelmente um odor de marisco (RUYRA, 1909, p. 59, tradução nossa). ${ }^{4}$

Figura 1 - Ulysses and the Sirens (1891), John William Waterhouse

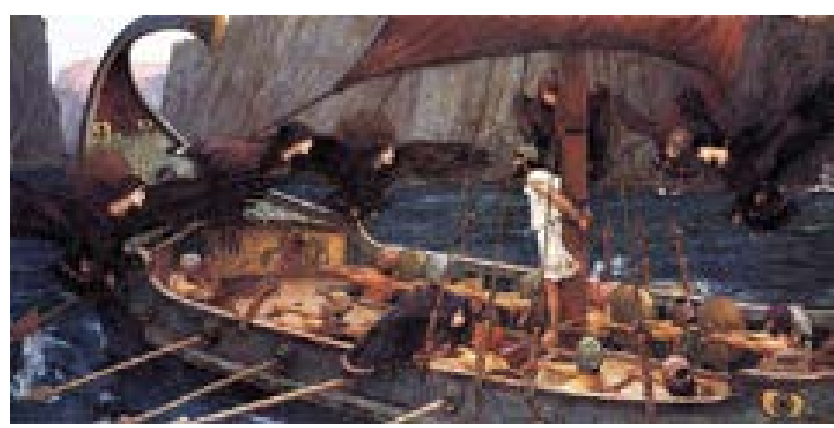

Fonte: Wikipedia commons.
Ruyra não faz uma representação literal do mito, como John William Waterhouse o fez em 1892, nas suas versões feminina e masculina, porém o descreve em um episódio vinculado ao plano geral de suas narrativas sobre os pescadores e que poderia ser um prolongamento de "Una tarde en el mar" (1909). O autor preferiu contar uma versão poética, não se sabe até que ponto mesclada às histórias e lendas dos pescadores que inspiraram muitas de suas narrativas. Porém, as donzelas do conto de Ruyra não seriam mitos urbanos, devido "a sua ecologia":

Não se pense que as assombrações mais características [...] não têm a sua ecologia. A história natural às vezes limita a sobrenatural. São as assombrações do Recife assombrações de cidade, para a qual "caipora”, "boitatá", "curupira", "saci-pererê" são entes fora-de-portas. Mitos rústicos e não urbanos (FREYRE, 2000, p. 32).

No trecho seguinte, Freyre expõe a intersecção entre história e mito, na lenda do Riacho da Prata. Faz ainda, menção aos “cabelos verdes”. Por estarem tão relacionados ao vigor da feminilidade, cabelos longos e tranças ondulantes, são característicos na descrição da sereia, que representaria, portanto, dois aspectos ameaçadores e monstruosos: o componente sexual da feminilidade e a percepção desse (MILLIKEN, 2012 p. 123). A versão do folclore recifense converte as "volantes Sirènes", "oiseaux maudits", de Guillaume Apollinaire, em um mito local das águas:

Mais adiante se falará na história da moça de quem contava, já muito velha, sua antiga mucama ter a iaiazinha desaparecido nas águas da Prata - ou do Prata - arrebatada pela própria Branca Dias sob a figura de mãe-d'água. Felizes das mulheres que na vida sobrenatural se transformam em bonitas mães-d'água alvas ou morenas, em sereias de olhos e cabelos verdes, em alamoas louras (FREYRE, 2000, p. 50).

4 Do original: Son blancas como la carne pálida del pez. En sus cabellos finísimos juegan tonalidades irisadas; brillan en sus cabezas peines de escama; sus mantos son verdes, son largos, largos, arrastradizos; por ojos, tienen gotitas de luz como las que a veces produce en el agua el roce de los remos. A su paso desprenden agradablemente un olor a marisco. 
Freyre (2000, p. 48) não limitou às costas do Brasil e às águas do Recife o espaço em "[...] que os olhos dos homens do mar ou dos moradores da beira-mar ou da beira dos rios ou dos simples riachos têm visto figuras que não constam dos compêndios de história natural: só da história sobrenatural”. Seria impossível abordar aqui a multiplicidade de descrições e variantes dessas figuras na literatura. José Cândido de Carvalho, em O Coronel e o Lobisomem (1970), reproduziu a imagem mítica da sereia do Liber Monstrorum, imbuída da tônica sobrenatural de ser encantado e sedutor, "Savent de mortelles chansons", conforme Apollinaire:

E na presença do luar apareceu aquele rosto de bonitezas, cabelo de ouro pingando água e boca cheirosa chamando por mim:

- Ponciano, Ponciano...

Mas, para desgosto meu, arrematava em rabo de peixe. Era uma sereia. (...) Acabada a conselhagem, gabei as cantorias dela:

- Estou ainda de ver garganta mais educada.

Dito isso, em braço carinhoso arrastei a cativa para o seco - o rabo ficou em bacia de mar, como é da lei das sereias. (...) Dei razão ao seu desgosto e quis botar meus préstimos e patente a serviço dela:

- Todo meu poder em armas e dinheiro em caixa é de Vossa Mercê. Rejeitou:

- Do Coronel só quero uma prenda.

Nesse ponto, a sereia baixou os olhos de verdes capins como pratica toda donzela de primeira mão. (...) Ainda tentei, num último arranco, segurar a encantada pelas tranças (CARVALHO, 1987, p. 106-109).

Homero e Ovídio ajudaram a fixar a imagem da sereia como ser de voz doce e perigosa. O triunfo de Ulisses sobre o canto das sereias impregnou o folclore das ilhas britânicas, relatando os perigos de encontros semelhantes (PERDERSEN, 2015, p. 12). Segundo Andrew e Catherine Belsey (1990, p. 11 apud PEDERSEN, 2015, p. 42), durante a Idade Média e a
Renascença, sereias representavam as destrutivas possibilidades da sexualidade. De acordo com as lendas, elas ofereciam tentadores vislumbres de sua beleza, enquanto penteavam seus longos cabelos dourados entre as ondas. Similares às mulheres aladas que ameaçavam destruir Ulisses e sua tripulação, as sereias também cantavam com incrível doçura e sedução. Atraídos por seus encantos, marinheiros que falhavam ao exercitar a mais severa autodisciplina lançavam-se ao mar. Submergiam frustrados na satisfação de seus desejos e logo os barcos desgovernados perdiam-se entre as rochas. Câmara Cascudo faz uma ressalva quanto à forma sedutora do mito na literatura nacional:

Não conheço no documentário brasileiro mãe-d'água cantando, moça bonita do cabelo louro e olho azul, senão na segunda metade do século XIX, e mais intensamente depois da reação romântica que se iniciou pelo indigenialismo transfigurador de Gonçalves Dias (CASCUDO, 1993, p. 533).

Bernardes, Ruyra e Carvalho extraem da imagem mitológica da sereia alguns dos seus atributos essenciais: a beleza, a ligação com o mar e a natureza sobrenatural. Se a forma hibrida ausenta-se nos textos de Benardes e Ruyra, apenas Carvalho registra "as cantorias dela". Em "Las damiselas" a sedução pela beleza não se associa ao canto, nem ao corpo, mas à expressão poética da palavra:

Finalmente, todas vão murmurando palavras misteriosas ao ouvido dos adormecidos. Falam da poesia de mar, do inusitado jogo das ondas, de suas belas cores que se alteram sem cessar; falam dos peixes e das plantas onde pascem; das tempestades, da serenidade, dos encantos de uma viagem sem fim, da sublimidade dos elementos desenfreados... de algo que nossas palavras não podem expressar. E os pescadores sonham, sonham tudo o que ls pequenas fadas lhes inspiram em voz baixa (RUYRA, 1909, p. 61, tradução nossa). ${ }^{5}$

5 Do original: Finalmente, todas van a murmurar palabras misteriosas al oído de los durmientes. Les hablan de la poesía del mar, del exquisito jugueteo de las ondas, de sus bellos colores que se truecan sin cesar; les hablan de los peces y de las hierbas donde pacen; de 
A sedução sexual destrutiva não é mostrada nos relatos de Freyre e Ruyra. Mas cada narrativa identifica o caráter sobrenatural do encontro com a sereia. Embora toda legenda esteja inextricavelmente conectada a uma crença, somente Bernardes (1865, p. 94) enfatiza uma relação didática específica entre o conteúdo da narrativa e um sistema de crenças particular: "Começou pois a brincar lascivamente com as ondas, e a lavar-se porventura com menos temperança do que pedia a presença de Deus, que um christão em toda parte deve trazer diante dos olhos".

As sereias de Ruyra e Freyre vinculam-se a um contexto social concreto, respectivamente, pela "presencia de los seis pescadores novicios"; da mucama, da iaiazinha e da "própria Branca Dias". Ainda, todos os relatos mencionam os cabelos: "finísimos" e de "tonalidades irisadas" "verdes" ou "de ouro pingando água”. Sem excluir a natureza humana de Branca Dias, estas figurações adaptativas do mito originam-se e convergem ao domínio da imaginação, do sobrenatural e das pulsões.

\section{Considerações finais}

Dos primeiros relatos sobre o Brasil aos autores contemporâneos, a imagem da sereia foi associada a dois modelos elementares: o mito da mulher marinha, desde Homero direcionado à promessa de prazer e conhecimento; e o mito indígena da mãe-d'água ou Iara, conectada pelo colonizador ao Ipupiara. Até o século XVII, cronistas e viajantes desenvolveram uma mitografia própria, emprestando ao elemento local características da sereia oriental aperfeiçoada pela cultura europeia, daí os Ipupiaras, homens e mulheres marinhos "de tão horrendo feitio", zoomorfizados, sem qualquer relação com os sofisticados artifícios de sedução das sereias de Homero.

Nas Idades Média e Moderna, nota-se o esforço dos discursos da religião e história natural em descrever as sereias por parâmetros próprios. A crônica histórica, testemunha do encontro entre diferentes culturas, e o relato marítimo de cunho maravilhoso explicaram-nas, segundo as palavras de Gândavo, como "alguma visão demoníaca" prefigurada pelo "sisudo" e "esforçado" europeu e "esta gente da terra [...] digna de pouco crédito". De natureza demoníaca, de "hadas", "sob a figura de mãe-d'água", "encantada”, em sua exuberância pitoresca, fantástica: “[...] parecem mulheres; têm os cabelos compridos e são formosas" (CARDIM, 2009, p. 151).

No Brasil e na Europa, com a valorização da erudição acadêmica, principalmente do estudo folclórico voltado à reformulação da identidade nacional, os séculos XIX e XX tomaram-nas por "mitos rústicos", "entes fora-de-portas" da "história sobrenatural" das sociedades humanas. Nos exemplos literários analisados, observou-se que fontes medievais do mito inspiradas na legenda e herança clássica foram incorporadas ao relato moderno de cunho exemplar, folclórico e maravilhoso.

A descrição feita por Ruyra absorveria igualmente a riqueza simbólica do mito nessas três acepções. Quando "las Damiselas marinas", "pequeñas hadas", visitam o sono dos jovens pescadores e "les inspiran en voz baja”, adquirem o significado de musas e porta-vozes da tradição na cultura oral e erudita. Logo, o mito não advertiria apenas sobre o perigoso desejo por conhecimentos e prazeres fatais, mas sobre o prazer e o saber facultados pelo sonho e pela imaginação criativa.

\section{Referências}

AZEVEDO, Ana Maria. Introdução. In: CARDIM, Fernão. Tratados da Terra e Gente do Brasil. Introdução e organização de Ana Maria de Azevedo. São Paulo: Hedra, 2009. p. 9-78.

BARLÉU, Gaspar. História do Brasil sob o governo de Maurício de Nassau (1636-1644). Tradução do original, notas e prefácio de Blanche T. van Berckel-Ebeling. Recife: Cepe editora. 2018.

BERNARDES, Manuel. Lenda da mulher marinha. In: CASTILHO, Antônio Feliciano de. Manuel Bernardes: Excertos. Rio de Janeiro: Livraria de B. L. Garnier, Editor, 1865. p. 94-8.

BURKE, Peter. Revolution in Popular Culture. In: HINDS, Harold E.; MOTZ, Marilyn Ferris; NELSON, Angela M.

las tempestades, de la serenidad, de los encantos de un viaje sin fin, de la sublimidad de los elementos desaforados... de algo que nuestras palabras no pueden expresar. Y los pescadores sueñan, sueñan todo lo que las pequeñas hadas les inspiran en voz baja. 
S. (eds.). Popular Culture Theory and Methodology. Madison, Wiscosin: The University of Wisconsin Press, 2006. p. 30-46. https://doi.org/10.1017/s0021875806423458

CARVALHO, José Cândido de. O Coronel e o Lobisomem. Rio de Janeiro: Livraria José Olympio, 1987. https://doi. org/10.11606/t.8.2008.tde-27032012-163120

CASCUDO, Luís da Câmara. Dicionário do Folclore Brasileiro. Rio de Janeiro: Ediouro, 1993. https://doi.org/10.2307/335622

CICALA, John Alan. Ethnic Folklore. In: CAYTON, Andrew R. L.; SISSON, Richard; ZACKER, Chris (eds.). The American Midwest: An Interpretive Encyclopedia. Bloomington, Indianapolis: Indiana University Press, 2007. p. 405-407.

DÉGH, Linda. Legend and Belief: Dialectics of a Folclore Genre. Bloomington/ Indianapolis: Indiana University Press, 2001.

FREYRE, Gilberto. Assombrações do Recife Velho. Rio de Janeiro: Topbooks, 2000.

GÂNDAVO, Pero de Magalhães de. A Primeira História do Brasil: História da província Santa Cruz a que vulgarmente chamamos Brasil. Modernização do texto original de 1576 e notas de Sheila Moura Hue e Ronaldo Menegaz. Rio de Janeiro: Jorge Zahar Editor, 2004. https://doi.org/10.11606/t.8.2015.tde-06102015-150046

JEANNELLE, Jean-Louis; PHILIPPE, Gilles. La "littéraIrité" à l'épreuve d'une histoire des pratiques littéraires. In: JEANNELLE, Jean-Louis; PHILIPPE, Gilles. Le mot juste. Paris: Presses Sorbonne Nouvelle, 2006. p. 39-50. https:// doi.org/10.1353/ahs.2016.0102

LANCIANI, Giulia. Os relatos de naufrágios na literatura portuguesa nos séculos XVI e XVII. Instituto de Cultura Portuguesa, Presidência do Conselho de Ministros, Secretaria de Estado da Cultura, 1979. https://doi.org/10.14195/978989-26-0405-3 4

MILLIKEN, Roberta. Sirens and Mermaids. In: MILLIKEN, Roberta. Ambiguous Locks: An Iconology of Hair in Medieval Art and Literature. Jefferson, North Carolina, and London: McFarland \& Company, Inc., Publishers, 2012. p. 123-33. https://doi.org/10.1086/685890

OSWALD, Dana. Monstrous Gender: Geographies of Ambiguity. In: MITTMAN, Asa Simon; DENDLE, Peter J. (eds.). The Ashgate Research Companion to Monsters and the Monstrous. Ashgate, 2012. p. 343-364. https://doi. org/10.1108/09504121311290435

PEDERSEN, Tara E. Mermaids and the Production of Knowledge in Early Modern England. Farnham and Burlington: Ashgate, 2015.

PRIORE, Mary Del. Esquecidos por Deus: Monstros no Mundo Europeu e Íbero-Americano (Sèculos VI-XVIII). São Paulo: Companhia das Letras, 2000.

RUYRA, Joaquim. Jacobé: narraciones del mar y la montaña. Barcelona: E. Domenech, 1909. p. 57-61.

SHANKMAN, Steven Shankman; DURRANT, Stephen W. The Siren and the Sage: Knowledge and Wisdom in Ancient
Greece and China. London, New York: Cassell, 2000. https:// doi.org/10.2307/3109452

SCHLANGER, Judith. La Mémoire des oeuvres. Paris: Nathan, 1992.

SOUSA, Gabriel Soares de; VARNHAGEN, Francisco Adolfo de. Tratado descriptivo do Brazil em 1587. Rio de Janeiro: Typographia Universal de Lammert, 1851.

VERNER, Lisa. The Epistemology of the Monstrous in the Middle Ages. London, New York: Routledge, 2005.

VIEIRA, Antônio. Sermão de Santo Antônio aos Peixes. In: VIEIRA, Antônio. Sermões, II. Lisboa, Centro de Estudos de Filosofia; Imprensa Nacional-Casa da Moeda, 2010. https:// doi.org/10.17851/2359-0076.30.43.187-191

Recebido em: 1/5/2017.

Aprovado em: 6/4/2019.

\section{Maria Alice Ribeiro Gabriel}

Universidade Federal da Paraíba (UFPB)

Orcid: http://orcid.org/0000-0003-0256-1306

E-mail: rgabriel1935@gmail.com

Endereço de correspondência: Av. Dr. Soares de

Oliveira, 816, Centro, Ituverava - SP. Cep: 14500-0oo 